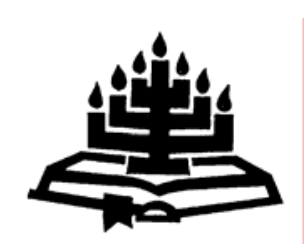

\title{
Opwekking binnen de traditioneel- reformatorische kerken: over oprecht verlangen en grote verlegenheid
}

\author{
J. Kommers \\ Reformed Mission League (GZB) \\ MOÇAMBIQUE \\ E-mail: j-a.kommers@hotmail.com
}

\begin{abstract}
Revival within churches from traditional-reformed origin: on sincere longing and extreme embarrassment

Within churches from reformed origin the debate about revival has become an actual issue. It seems that these churches are becoming smaller and smaller, and that there is a lack of missionary zeal. Many pastors seem to have lost the courage to go on. What is happening in the churches? One can learn something from the history of the church. What was God doing in the past? The Word of God was there and it seems that in those places where revivals broke out, the Word of God was preached faithfully, in the power of the Holy Spirit. From sermons of three revival preachers who worked from 1816 to 1880 in Wuppertal (Germany), one can learn how their sermons contributed to revival in those days.
\end{abstract}

The missionary-soul caring message struck the people in their hearts, and not only individuals, but also whole regions changed; change took place not only in doctrine and lifestyle, but also holiness occupied a central place in the people's hearts. When praying for the outpouring of the Holy Spirit, people will repent and turn to God and "times of refreshing may come from the Lord" (Acts 3:19).

Opsomming

Opwekking binnen traditioneel-reformatorische kerken: over oprecht verlangen en grote verlegenheid

De vraag naar opwekking binnen de reformatorische kerken is in onze tijd weer actueel geworden daar het voorkomt dat deze kerken steeds kleiner worden, het missionaire élan ontbreekt en veel voorgangers de moed lijken te hebben verloren om verder 
te gaan. Wat gebeurt er in de kerken? Vanuit de geschiedenis is het een en ander te leren. Wat deed God in het verleden? Wij hebben het Woord van God en het blijkt dat dáár waar opwekkingen zijn geweest het Woord getrouw, in de kracht van de Heilige Geest wordt gepreekt. Aan de hand van preken van drie opwekkingspredikers die in de periode 1816-1880 in het Wuppertal (Duitsland) hebben gewerkt, willen wij nagaan in hoeverre zij de opwekking in hun tijd door de prediking hebben begeleid.

De missionair-zielzorgelijke prediking trof de mensen in hun harten en niet alleen enkele personen, maar ook hele landstreken veranderden en nam de heiliging, zowel in de leer alsook in het leven, een grote plaats in. In het gebed om het neerkomen van de Heilige Geest zal het werkelijkheid worden; dat waar mensen boete doen en zich wenden tot God, "er tijden van verademing mogen komen van het aangezicht des Heren" (Hand. 3:19).

\section{Verlangen naar opwekking}

Om met een persoonlijke noot te beginnen: ik ben er diep van overtuigd, dat wat God aan zijn kerk gegeven heeft op de Pinksterdag in Jeruzalem niet voor eens en altijd is geweest. Waar er een roepen en smeken is tot God om de Heilige Geest, daar zal van Godswege het antwoord komen en de Heilige Geest zal harten en levens van mensen aangrijpen en vernieuwen. In Jeruzalem is de Heilige Geest met grote kracht en heerlijkheid gekomen op de mensen die daar waren samengekomen en die gebeden hebben om die Geest. Maar Pinksteren gaat door. Dat, wat ons als belofte is gegeven in Galaten 3:16, daarop blijven wij aan het begin van de eenentwintigste eeuw hopen met intens verlangen: "opdat wij de belofte van de Geest verkrijgen zouden door het geloof ". God zal opnieuw zijn kracht en zijn heerlijkheid ons openbaren en zullen wij een opwekking, door Hem bewerkt, meemaken! "We ought not to limit God where he has not limited Himself" (Edwards, 1999:89). Het is goed om te lezen en ook bemoedigend voor ons nu, wat God in de geschiedenis van zijn kerk gedaan heeft, maar wij die nu leven, mogen van God ook nu die krachten en gaven verwachten voor de kerk aan het begin van de 21 ste eeuw zoals Hij die gegeven heeft in de eeuwen achter ons. Opwekkingen zijn geen gebeurtenissen die alleen in het verleden plaatsvonden. Omdat God in zijn trouw dezelfde is en zijn kerk niet loslaat, mogen wij van Hem verwachten dat Hij opnieuw zijn kerk bezoekt en zich op een bijzondere wijze aan haar openbaart. Bavinck (z.j.:17) wijst erop dat de kerk ten onrechte een streep heeft gezet tussen de periode van de apostelen 
en de latere tijden. Wij veroordelen onszelf tot schraalheid en armoede wanneer wij de ervaarbare werking van de Heilige Geest inperken tot de eerste periode van de kerk.

\section{Wat is een opwekking?}

Wat bedoelen wij met opwekking? Het woord opwekking werd in de achttiende en negentiende eeuw zowel in Europa als in Amerika gebruikt voor een "geweldige bezoeking van God aan zijn volk" (Barrs \& Packer, 1998:145). Dit gebeuren is aangeduid als Awakening, Revival, Réveil, Erweckung. In Amerika gebruikte Jonathan Edwards ook de term renewal. Dit is vernieuwing, een herstel van het leven. Opwekking is een herstel van het bewustzijn (Barrs \& Packer, 1998:145). Zowel opwekking als vernieuwing willen hetzelfde zeggen. God heeft ons bezocht. Hij schudde ons wakker uit de slaap van onze geestelijke dood en Hij brengt ons weer tot leven. In de Bijbel staan gebeden om een persoonlijke opwekking (bv. Ps. 51:20; Ps. 85:5; Ps. 119 en Jes. 57:15). In Openbaring 2:1 wordt de Christelijke gemeente te Efeze opgeroepen om met vernieuwde toewijding God te zoeken. Het gaat hier om een heel existentiële zaak. In het gebed van de profeet Habakuk (3:2) wordt gebeden om herleving: "Uw werk, o HEERE! Behoud dat in het leven (revive) in het midden der jaren, maak het bekend in het midden der jaren; in de toorn gedenk des ontfermens." Het is de Heilige Geest - de bron van dit verlangen naar God. Hij helpt ons om heel concreet te bidden om een opwekking in het persoonlijke en het kerkelijk gemeenteleven. Opwekking in Bijbels licht is volgens G. Campbell Morgan de reanimatie van het leven van de gelovige. "There can only be revival where there is life to revive" (Hughes, 1990:12). "The quickening of the saints is the root, while the saving of the sinners is the fruit of all revivals" (Wallis, 1956:49). De beroemde prediker uit Wales, Christmas Evans, geeft de volgende sterke definitie van een opwekking: "Revival is God bending down to the dying embers of a fire that is just about to go out, and breathing into it, until it bursts again into flame" (Hughes, 1990:13). Alle opwekkingen in de geschiedenis zijn in zekere zin een terugkeer naar Pinksteren. Bij opwekkingen is de Heilige Geest prominent aanwezig. Op de vraag: Wat is een opwekking?, antwoordt LloydJones dan ook heel beslist: "Revival is an outpouring of the Spirit of God. It is a kind of repetition of Pentecost. It is the Spirit descending upon people" (Lloyd-Jones, 2002:289). Het is onmogelijk om een opwekking in de geschiedenis aan te wijzen waar er niet een buitengewoon gevoel zijn van Gods majesteit en heiligheid. Opwekking begint bij God. "Zult Gij ons niet weer levend maken, 
opdat Uw volk zich in U verblijde?" zo bidt in Psalm 85:7 de dichter. God is niet alleen de bron van een opwekking ("Zult $U$ ons niet weer levend maken"), maar Hij is ook het einddoel van een opwekking ("opdat Uw volk zich in U verblijde"). Opwekking onderscheidt zich van evangelisatie. Evangelisatie is het werk dat mensen doen voor God, maar opwekking is het werk dat God doet door de Heilige Geest voor de mensen, waarbij zijn doel is om heerlijkheid te geven aan zijn Naam. Opwekking begint daar, waar Gods Naam over zijn volk wordt uitgeroepen en het volk zich "verootmoedigt en bidt, en zij Mijn aangezicht zoeken, en zich bekeren van hun boze wegen; zo zal Ik uit de hemel horen, en hun zonden vergeven, en hun land genezen" (2 Kron. 7:14). Opwekking is een manifestatie van God. God openbaart zichzelf in volle indrukwekkende heiligheid en onweerstaanbare kracht. God komt neer en bezoekt zijn volk. Kenmerkend voor de prediking voorafgaand of tijdens opwekkingen is de concentratie op Christus als de Enige Zaligmaker van de mensen (vergelijk de drie preken van Whitefield in Macfarlan, 1988:3-49). Een opwekking mag worden verwacht als antwoord op het gebed. God stort zijn Geest uit als antwoord op het gelovig gebed!

De lamheid en de lauwheid binnen de kerken kan ons neerdrukken, maar nochtans geloven wij dat onze God een tijd vol van genade geven zal. Het is bij velen een oprecht verlangen en ook zijn er weer veel jongeren die het te doen is om de werkelijkheid van het geloof en die ook intens bezig zijn met de Bijbel en Gods beloften voor de toekomst van zijn kerk uit te spellen. Men signaleert een oprecht verlangen, maar daarbij komt direct een grote verlegenheid wanneer het gaat om opwekking. Predikanten en ouderlingen, werkzaam binnen een van de vele kerken van reformatorische origine kijken dikwijls met enige verbaasdheid en ook met een zekere jalousie naar kerken met een wat vrijere evangelische structuur. Binnen de traditionele kerken zijn grote groepen mensen die zich niet meer aangesproken weten door de prediking en verlaten massaal de kerk. Het is lang geleden dat opwekkingen binnen deze kerken hebben plaatsvonden. In andere kerken daarentegen is een geweldige groei en worden de kerkgebouwen te klein om aan de grote schare van mensen een plaats te kunnen geven. Binnen verschillende traditioneel reformatorische kerken is een proces bezig van evangelische bewegingen waarbij geprobeerd wordt om los te komen van het in hun ogen starre, orthodox kerkelijk gebeuren. "Geef de Geest de ruimte", zo klinkt het dan. Hiervan is de in 1995 ontstane evangelische beweging binnen de Protestantse Kerk in Nederland (Eschbach, z.j.) een voorbeeld. 


\section{Het ontbreken van opwekkingen}

Wat is er aan de hand binnen onze reformatorische kerken? Wanneer er iets fout zit in ons traditioneel kerkelijk gebeuren, wat gaat er dan fout, en wat is niet in orde? Wordt bijvoorbeeld door de gereformeerde ambtsopvatting en door de orde van dienst een blokkade opgeworpen tegen de Heilige Geest? Wij geloven dat de boodschap van de Bijbel een krachtig, levenwekkend getuigenis is en dat door de prediking van het Woord God grote dingen worden uitwerkt. De Reformatie is vooral een preekbeweging geweest, ontstaan door het hernieuwde onderzoek en het lezen van de Bijbel. Daardoor werden velen geraakt in hun harten en levendige gemeenten zijn er door ontstaan. Het evangelie ging als een lopend vuur en in veel gebieden werkte de Heilige Geest krachtig en was er sprake van opwekkingen. Opwekkingen die in de tijd na de Reformatie in verschillende landen op verschillende tijdstippen zijn voorgekomen. Terugziende op de laatste eeuw dan moeten we concluderen dat de twintigste eeuw arm is geweest aan geestelijke herlevingen al is er in die eeuw door de kerken veel werk verzet om dit te bewerken.

Hoe komt het dat binnen zoveel reformatorische kerken er een zekere lauwheid heerst? In de brochure Olie op het vuur (Eschbach, z.j.) wordt aangegeven, dat door het secularisatieproces de kerk geprobeerd heeft de Bijbelse boodschap aan te passen aan de moderne mens. Maar de kerk is niet duidelijk genoeg met de blijde boodschap de wereld ingegaan om aan verloren mensen klaar en helder het getuigenis van God te verkondigen, maar het tegendeel gebeurde: de wereld kwam de kerk binnen en ontstond er in de kerken het moreel en geestelijk verval (Eschbach, z.j.:7). Zo gebeurt het dat de kerk voor de jonge mensen geen aantrekkingskracht meer heeft, de tweede dienst op de zondag dikwijls al is afgeschaft, gemeenten niet meer in staat zijn de predikanten te kunnen onderhouden, de catechese geworden is tot een vrijblijvend gespreksuurtje, het ledental dramatisch daalt en enkele ijveraars met man en macht proberen het geheel nog draaiende te houden. De preekpraktijk van veel reformatorische kerken waarin het sola fide elke zondag vanaf de kansel klinkt, bewerkt in onze tijd meestal geen opwekking meer. Eerder is er sprake van een zekere preekmoeheid in deze en worstelen veel voorgangers van gemeenten met een reformatorische traditie ermee om de heilswaarheden overgeleverd via de Reformatie, vandaag de dag opnieuw te vertolken. Rudolf Bohren heeft verzucht, dat de theologie van vandaag de centrale boodschap van de Reformatie nauwelijks 
meer ter sprake weet te brengen. "Die Botschaft von der Rechtfertigung der Gottlosen - das zeigen die Predigtanalysen zur Genüge - wird zu einem Glaubenssatz ohne Gläubigkeit, zu einem Etikett, das ganz andere Inhalt verdeckt" (Bohren, 1975:25). Vandaag de dag is er wijdverspreid een nominaal Christendom waar het ontbreekt aan een demonstratie van de kracht van de Heilige Geest. "Many times before has the work of preaching fallen into such ineffectiveness as is to be seen at present" (Murray, 1998:103). Het blijkt ook, dat wanneer de grote cruciale Bijbelse grondwaarheden niet meer worden uitgesproken en daarover niet meer gepreekt wordt, ze dan langzamerhand verdwijnen uit de beleving van het kerkvolk. In de geschiedenis van de kerk blijkt het, dat grote bewegingen in de kerk, zoals de Reformatie, het Réveil, en de Awakening steeds werden aangekondigd en voorafgegaan door een herleving van de prediking.

\section{Lessen uit de geschiedenis}

Uit het onderzoek (Kommers, 2005) waarin preken van enkele uitgesproken gereformeerde opwekkingspredikers uit de negentiende eeuw zijn bestudeerd, is gebleken dat deze predikanten op een indringende, pastorale manier de hoorders van hun tijd wisten aan te spreken met de kernboodschap van de Reformatie. Binnen de traditionele kerken (gereformeerd en luthers) kwam een Erweckung (opwekking) en hebben mensen de grote kracht en heerlijkheid van God ervaren. Het is goed om terug te kijken in de geschiedenis van de kerk om daarin het handelen van God in de eeuwen voor ons op het spoor te komen en zo moed vatten voor onze tijd en de toekomst. De predikanten waar het hier om gaat werkten binnen de traditioneel kerkelijke gemeenten in het Wuppertal (Duitsland) en gebruikten voor hun prediking de deductieve (afleidende) methode, waarbij Bijbeluitleg op de eerste plaats stond. Zij waren er niet op uit om hun hoorders te amuseren of om indruk op hen te maken. Ook waren diensten waarin zij voorgingen geen therapeutische sessies waarin ingezoomd werd op de noden en vragen van de hoorders. Gebruik makend van de reformatorische beginselen preekten zij eenvoudig en tegelijk diep Jezus Christus als de Heer en Zaligmaker in de kracht van de Heilige Geest.

Binnen een tijdsbestek van ongeveer zeventig jaren ontstonden enkele opwekkingen binnen de al enkele eeuwen bestaande gereformeerde en lutherse kerken in het Wuppertal. De prediking zoals die daar in die tijd gehouden is definieert Rusking als: "Thirty 
minutes to raise the dead" (Thomas, 1997:15). Mensen stonden op uit de (geestelijke) dood en vonden het leven in Christus. Als doel van de preken zag men: "Die Predigt des Evangeliums ist, was Inhalt und Umfang betrifft, im Grunde nichts anderes als eine Verkündigung, dass die Toten auferstehen werden" (Geyser, 1923: 47). Het is opmerkelijk dat in die tijd wereldwijd opwekkingen plaatsvonden en daarbij is steeds het patroon dat geestelijk doden levend werden. Om een voorbeeld te noemen: ver weg van het Wuppertal in Duitsland vond in juni van het jaar 1813 een opwekking plaats in Griquatown (Zuid-Afrika). De zendeling William Anderson beschreef de beweging daar als "life from the dead" (Orr, 1975:129). In diezelfde tijd vonden ook opwekkingen plaats op zendingsstaties waar nu Port Elizabeth ligt. Deze opwekkingsbeweging kenmerkte zich "by strong conviction of sin and by tears, and it arose through strong preaching" (Orr, 1975:129).

In onze tijd is er een groeiende aandacht voor deze zaken. Het zou wel eens zo kunnen zijn, dat wij eerlijk tegen elkaar moeten zeggen in de kerk dat al onze (goed bedoelde) activiteiten niet dat heeft opgeleverd wat wij ervan hebben verwacht. In onze emotiecultuur wordt heel veel gevraagd van de mens die zijn ervaring en activiteit moet etaleren, maar op een geven moment daar o zo moe van wordt. De werkelijkheid is weerbarstiger, maar daar, waar wij met de rug tegen de muur staan en niet weten hoe het nu verder moet, is de weg naar boven open om reikhalzend uit te zien dat God zal spreken en wij zijn sterke hand opmerken. Gelovend: God zal zich openbaren en zijn kerk bezoeken met zijn heil! Opwekking is, omdat het alles zo beweeglijk is (werk van de Heilige Geest!) niet zo vastomlijnd te definiëren, maar we kunnen wel de richting aanwijzen. In de prediking gaat het erom dat deze leidt tot een geestelijke opleving waarbij de prediker zelf met hart en ziel bij betrokken is.

Bij alle tijds- en regionale verschillen is karakteristiek voor een opwekkingsbeweging dat het een elementaire boetebeweging is en dat het probeert de mensen weer naar het eenvoudige, heldere Bijbelgeloof terug te leiden. Hierdoor komen de reformatorische uitgangspunten opnieuw aan het licht. Het is opmerkelijk dat bijna gelijkertijd in verschillende delen van Duitsland aan het begin van de negentiende eeuw een opwekking heeft plaatsgevonden. Er waren in die tijd meerdere gebieden waar een opwekking plaats vond, bijvoorbeeld: Wuppertal, Württemberg en Allgäu. Men kan zeggen dat de opwekkingsbeweging een volksbeweging is geweest, een vroomheidbeweging. Om deze te verstaan moeten in de eerste 
plaats de preken en traktaten uit die tijd onderzocht worden. Gäbler (1991:170) ziet als karakteristiek wat tijdens een opwekking gebeurt, dat dan de analyse van de tijd met de heilsgeschiedenis in verbinding wordt gebracht.

In de eerste decennia van de negentiende eeuw veranderde het Wuppertal aanzienlijk. De ervaring van veel mensen uit die tijd was, dat er iets nieuws op handen was. "Es nahete eine neue Zeit in dem alten Thale" (Strauss, 1868:206). Door de talrijke veranderingen en gebeurtenissen van Europa omstreeks 1816 brak een nieuw tijdperk aan in de geschiedenis van God met de mensheid (Lehmann, 2000:2-26). Profetische literatuur verscheen en alles wees erop, dat deze wereldomvattende gebeurtenissen in de Bijbel al voorzegd waren. Dit biblicistisch motief laat de tegenstelling zien met de historisch-kritische Schriftuitleg, zoals deze in de Aufklärung werd beoefend.

In dit alles was de ervaring met God heel belangrijk. De Godservaring leidt van de religie van het verstand naar de religie van het hart. De ervaring die de mensen met God hadden werd geïdentificeerd met de ervaring die God de mensen liet maken van Hem. De interesse in het ingrijpen van God in het leven van de enkeling uitte zich in berichten over bekeringen en in autobiografische beschrijvingen van de wegen van God in het persoonlijke leven. De enkeling, de bekeerde mens werd sterk naar voren gehaald. De grote plaats die geestelijk onderlegde leken in het kerkelijk leven in het Wuppertal innamen, bewijst dat wel. Dit komt omdat de historische wortels van de opwekkingsbeweging in het piëtisme liggen (Beyreuther, 1978:331-346), waarbij tevens aangetekend moet worden dat ook de leidende figuren binnen de opwekkingsbeweging bijna zonder uitzondering allemaal piëtisten zijn geweest. Door de Wuppertaler predikant, G.D. Krummacher, is de opwekkingsbeweging in het Rijnland tot de wortels van de Reformatie teruggevoerd (Krummacher, 1935:159). De opwekking in het Wuppertal is heel duidelijk binnen het grote kerkelijke leven van het Wuppertal gebleven. Het was een uitgesproken missionair kerkelijke beweging.

Het is veel mensen aan het begin van de negentiende eeuw al opgevallen dat er een andere geest ging waaien in het Wuppertal en dat dit in de preken tot uiting kwam. Strauss (1960:169) stelt de vraag: 
Was ist es, das in den Predigten von Luther, Menken, Dräsecke, Kohlbrügge, aller mächtigen Prediger und besonders aller Sektirer so gross Gewalt ausübt, indess Schönrednerei, Moral und ähnliche menschliche Kunst die Zuhörer kalt lässt? Es ist die Erfahrung wahrer Redner. Es ist Glaube.

Wat is het geweest waardoor het in de preken veranderde? "Es ist Glaube", zo zegt Strauss. Het geloof, dat God doet wat Hij beloofd heeft. En Hij werkt door zijn Woord, krachtig, overtuigend, niet tegen te houden. Van de kant van de predikers werd geen speciale preektechniek gebruikt om mensen te overtuigen. Dat gebeurt bijvoorbeeld wel in een evangelisatiecampagne, maar bij een opwekking gebeurt dat niet. Bij een opwekking worden mensen door het getuigenis uit de Bijbel overtuigd van hun zonden, wenden zich tot God en hebben een sterke behoefte om ook anderen daarover te vertellen. "Het is een soort teken, dat God op deze manier geeft om Zijn werk in de Kerk te bevestigen, om Zijn volk te grondvesten en op te bouwen en het te bemoedigen" (Lloyd-Jones, 1992:142).

De geschiedenis laat zien dat opwekkingen dan plaatsvonden wanneer er een tijd van verootmoediging aan is voorafgegaan. Gezonde Bijbelse prediking vergezeld met een nederige afhankelijkheid van de zalving en kracht van de Heilige Geest. Dit laatste om duidelijk aan te geven dat de mens in het hele heilsproces geen enkele bijdrage kan leveren.

Het is goed om het ontstaan van de opwekkingsbeweging te verklaren, maar de vraag naar de theologische betekenis van de opwekkingsbeweging heeft haar eigen gewicht. Het woord beweging geeft al iets weer. Het geeft aan dat er leven is. Men is niet tevreden met wat voorhanden is, maar men wil nieuw zijn. Geen nieuwe leer, geen nieuw evangelie, maar nieuw leven door middel van het eeuwig blijvende Woord van God. Het evangelie zal zich als een kracht bewijzen. Het was die missionaire en vreugdevolle getuigenisactiviteit die zovele harten trof. Bekend is dat de opwekkingsbeweging in de negentiende eeuw het tijdperk van de zending - althans in Duitsland - heeft ingeleid. Men was niet tevreden met dat wat men had, maar er werd uitgezien naar dat wat God doet hier en nu én in de toekomst. Dit door het Woord van God dat zich bewijst te zijn "kracht van God tot zaligheid" en dat in staat is de grootste weerstand van het menselijk hart te breken. Zo is deze beweging een levensbeweging binnen de kerken, waarbij men binnen de opwekkingsbeweging zich niet alleen binnen de eigen confessionele grenzen heeft beperkt. In de eerste helft van de negentiende eeuw werkten de gereformeerden sterk samen met de 
Luthersen. Toen Strauss (1786-1863) in 1822 als predikant afscheid nam van Elberfeld wegens zijn vertrek naar Berlijn, hield hij niet alleen in de lutherse, maar ook in de gereformeerde kerk een afscheidspreek! Over en weer stonden de gereformeerde en de lutherse predikanten in die tijd bij elkaar op de kansel (Krummacher, 1935:152). Daar, waar men zich weer concentreert op de kernwaarheden van de Schrift en Christus Jezus in het centrum staat, daar is ook de ontdekking dat er broeders en zusters zijn in andere kerken, die hetzelfde belijden. Wanneer confessionele verschillen sterker worden benadrukt daar wordt de basis om met elkaar samen te werken smaller. Ook dat is te zien in het Wuppertal van de negentiende eeuw. Vanaf de jaren vijftig van de negentiende eeuw is te zien, dat in het Wuppertal de confessionele verschillen sterk werden aangezet, waardoor de broederlijke samenwerking onder grote spanning kwam te staan. Het preken op elkaars kansel was daar althans over.

\section{Achtergrond}

Het Wuppertal in het Westen van Duitsland is eeuwenlang het gebied geweest waar de reformatorische prediking bijna ononderbroken vanaf de Reformatie geklonken heeft. In de achttiende en negentiende eeuw waren hier veel piëtistische kringen die binnen de bestaande kerken grote invloed uitoefenden. Het piëtisme zag zichzelf als een reformatiebeweging voor de kerk en ontving haar impulsen uit de uitleg van de Bijbel. Naar het woord van Martin Kähler is de verdienste van het piëtisme het "Wachhalten der reformatorischen Fragestellung" (Schmitz, 1956:59). De vraag: "Hoe krijg ik een genadig God?" mag in de kerk nooit verstommen. In de negentiende eeuw, na de val van Napoleon ontstond in heel Duitsland een nieuw ontwaken. Zowel op politiek, maatschappelijk als op geestelijk gebied begon het overal te herleven. Die tijd was spanningsvol. De voorspelling van Johann Albrecht Bengel (16871752) dat 1836 het jaar zou zijn van de wederkomst van Christus, hield bij velen de spanning levendig: Christus is komende! Dit geeft aan de preken uit die tijd een zekere geladenheid. De opwekkingsprediker Tholuck (1799-1877), die tientallen jaren aan de universiteit te Halle doceerde, kenmerkte in 1821 zijn tijd als Auferstehungszeit (Tholuck, 1823: voorwoord). Binnen enkele tientallen jaren veranderde Elberfeld, waar een groot deel van de bevolking leefde van de huisindustrie, in een grote industriestad. Handelscontacten ontstonden met alle grote steden van Europa. 
Ook binnen de kerken - in Elberfeld was een grote lutherse en een gereformeerde kerk - was de opleving duidelijk te zien. Toen in 1816 Gottfried Daniel Krummacher predikant werd te Elberfeld ontstond kort daarna een opwekking onder jongeren in het Weeshuis en deze opwekking sloeg over naar de ouderen. Op werkdagen hoorde men de arbeiders de preek van de afgelopen zondag herhalen en werden er geestelijke liederen gezongen. Bij veel wevers lag de Bijbel open naast het weefgetouw. Ouderlingen en andere belangstellende gemeenteleden kwamen in de week samen om de Bijbel te bestuderen en in Barmen, een buurgemeente van Elberfeld, waren diverse ouderlingen die zondags het Griekse Nieuwe Testament open voor zich hadden liggen op de bank en de uitleg van de predikant nauwkeurig volgden. Er was in die tijd een honger om preken te horen. "Wij willen preken hebben, en lange preken willen wij hebben", zo zei het kerkvolk. De schrijver Herzog (1869-1943) schetst in zijn beschrijving van een zondagmorgen in het Wuppertal (Herzog, s.a.) de sfeer zoals die in Elberfeld en Barmen tijdens die opwekkingstijd moet zijn geweest. Het was alsof het voorportaal van de kerk tot aan de huizen reikte. Herzog wil hiermee aangeven dat de kerk in het leven van de mensen in het Wuppertal een bijzonder grote plaats innam.

De Bijbel, de Heidelberger Catechismus, het gebed- en gezangboek waren voor een groot deel van de bevolking de bronnen waaruit voor het geestelijk leven geput werd (Zahn, 1881:43-44). In de negentiende eeuw zag men als dé opgave van de evangelische prediking: de opwekking van de gemeente en de opbouw van de gemeente. "Erweckung und Erbauung, indem hierdurch sowohl die Ehre Gottes, als das wahre Heil der Menschen erzielt wird" (Christlieb, 1893:79).

Het was echter niet alles goud wat er blonk. In diezelfde tijd toen het geestelijk leven zo opbloeide zien wij ook de opkomende sociale ellende, de verpaupering van een groot deel van de bevolking, erbarmelijke werkomstandigheden, openbare prostitutie en kinderarbeid. Ook dit kwam voor in het "vrome Elberfeld". Hier brak in 1848 de revolutie uit en brachten Friedrich Engels (afkomstig uit piëtistische huize!) en Karl Marx hun communistische ideeën onder het volk. Binnen dit geheel hebben drie predikanten, Gottfried Daniel Krummacher (1774-1837), Hermann Friedrich Kohlbrügge (18031875) en Paul Geyser (1824-1882) hun sterk appellerende prediking in Elberfeld gehouden. (Voor de biografische notities van deze predikers, zie Kommers, 2005: de hoofdstukken VI, VII en VIII.) 


\section{De drie mannen van het Wuppertal}

De drie hierboven genoemde predikanten waren dé uitgesproken predikers in de tijd waarin de opwekking in het Wuppertal plaatsvond. Zij zijn het geweest die door hun prediking en pastoraat de opwekking daar hebben gevoed en begeleid. Het Wuppertal van die tijd was bekend vanwege de vele orthodoxe, piëtistische stromingen alsmede diverse visionäre bewegingen. Vanaf 1830 is het vooral door de grote geestelijke invloed van Krummacher, dat deze verschillende stromingen samengekomen zijn en in een gezond kerkelijk kader verder werden geleid. Hoewel deze predikers niet tegelijk in Elberfeld werkzaam waren zijn er een aantal bijzonderheden die ze alle drie hadden en vooral in hun prediking was het alsof de een het werk van de ander voortzette.

Geen van deze drie predikanten was afkomstig uit het Wuppertal. Krummacher is geboren in Tecklenburg en kwam na een diep geestelijke crisis tot volle overgave aan Christus en omhelsde volledig de reformatorische beginselen. $\mathrm{Na}$ in Baerl en Wülfrath predikant te zijn geweest kwam hij in 1816 naar Elberfeld. In de rij van opwekkingspredikers in het Wuppertal stond Krummacher "an ihrer Spitze" (Benrath, 2000:186).

Kohlbrügges familie kwam oorspronkelijk uit Duitsland, maar zelf was hij groot geworden in Amsterdam en is hulpprediker in de Lutherse kerk aldaar geworden. Omdat hij zich verzette tegen de onrechtzinnige leer in zijn kerk werd hij geschorst en week hij na vele moeizame jaren in Nederland uit naar Duitsland, waar hij in 1848 de eerste predikant werd van de Niederländisch Reformierte Gemeinde. Hij was in voorgaande jaren overtuigd geworden van de gereformeerde beginselen, maar in zijn hart en ook in zijn preken wordt het duidelijk dat hij luthers dacht.

Geyser komt oorspronkelijk uit Zwitserland. Hij begon aan verschillende studies, maar kreeg snel problemen met zijn superieuren. Hij vertrok naar Amerika waar hij naar eigen zeggen leefde van de "tabak en de alcohol". Geestelijk en lichamelijk een wrak geworden zorgde God ervoor dat hij in contact kwam met een Christenbroeder. Hij begon opnieuw zich te verdiepen in de Bijbel en keerde na enkele jaren terug naar Zwitserland om zijn ooit begonnen theologie studie af te ronden. Als hulpprediker werd hij na enkele preken gehouden te hebben, al direct geschorst omdat hij fel de onrechtzinnigheid van de heersende theologie hekelde. Tot veler verrassing en ook van hemzelf werd hij in 1856 beroepen in Ringstedt, helemaal in Noord-Duitsland. In 1861 kwam hij naar 
Elberfeld. Hij was daar beroepen in de vacature Ball, die op zijn beurt weer in de plaats van Krummacher gekomen was.

Alle drie hebben een gedegen theologische opleiding gehad. Zij kenden de Bijbelse grondtalen uitstekend en zowel op het gebied van de filologie alsmede in het brede spectrum van de theologische disciplines waren ze goed thuis. Geyser is meermalen aanbevolen als hoogleraar. Nog tegen het eind van zijn leven werd hij gepolst om de leerstoel Oude Testament aan de op te richten Vrije Universiteit te Amsterdam te gaan bezetten. Kohlbrügge is nog genoemd als hoogleraar Bijbelse talen in Leiden. Maar als gemeentepredikant hebben zij gezien, dat hun theologie hen niet van de gemeente diende te isoleren. Zo hebben zij het volle gewicht gelegd op de verkondiging van het Woord van God, de catechese en het pastoraat. Dus bij de openlijke Woordverkondiging kwam de cura specialis van veel, heel veel huisbezoeken.

Alle verkondiging en zielszorg had het bewuste doel dat mensen zouden komen tot de doorbraak, uit de dood tot het leven en om de mensen voor Jezus te winnen. De geschiedenis van de kerk laat ons ook zien, dat de meest gezegende predikers altijd ook goede zielzorgers zijn geweest.

Het gaat hier om drie predikanten die in een opeenvolgende periode vanaf 1816 tot 1882 in het Wuppertal gewerkt hebben. Het waren mannen die niet zo gemakkelijk waren in de persoonlijke omgang: hoekig, paradoxaal, eigenzinnig en soms wat wereldvreemd. Maar predikanten die zichzelf door God geroepen wisten en zich als profeten hebben gezien. Zij hadden diep ontzag voor de majesteit van God en hoog hebben zij opgegeven van de glorie en grootheid van Jezus Christus en zo krachtig hebben beleden zij het werk van de Heilige Geest. Alle drie hadden tot doel: "de ondoorgrondelijke afgrond van Gods genade te prijzen". De door hen geleide opwekking vanaf 1816 was theologisch gezien duidelijk een nieuw begin (Neuser, 1977:127).

Predikanten dienen, voordat ze gaan preken, goed bij zichzelf na te gaan: "Wat is het doel van mijn preek?", "Wat wil ik bereiken?" Een pijl zomaar in de lucht geschoten treft geen enkel doel. Zijn daarom zoveel preken niet vruchteloos omdat de predikers geen duidelijk doel voor ogen staat? Wil ik met mijn preek de zonde ontdekken? Troost bieden? De gemeente onderwijzen in de waarheid? Gods heilsgedachten, Gods heilsdaden uitspreken? De gemeente opbouwen in het allerheiligst geloof en tegelijk daarbij de missionaire 
spits van uitbouw? Het Griekse woord voor opbouw oikodomè heeft namelijk tevens de connotatie van uitbouw!

Voor de Wuppertaler opwekkingspredikers waren de volgende zaken werkelijkheden: God en zijn liefde, Christus en zijn kruis, de Heilige Geest en zijn werk in de harten van de mensen. Het evangelie van Gods rijke genade als dé enige remedie voor deze wereld. Kortom: verkondiging pur sang. Zij hebben tevens een omslag gebracht in de manier van preken en hebben het heersende homiletische schema van hun tijd doorbroken (Krummacher, 1935: 142). Veel predikers uit die tijd zaten vast aan een bepaald schema, bijvoorbeeld alleen een themaprediking of een in een strakke dispositie leerstellig betoog. Krummacher, Kohlbrügge en Geyser, vooral de eerste twee, hebben dikwijls gebruik gemaakt van homilieën en spraken tot de mensen en niet over de hoofden van de mensen heen.

Wat bij hen opvalt is dat ze fundamentele exegese bedreven. Ze waren goed thuis in de grondtalen van de Bijbel. ledere keer kom je bij hen exegetische verrassingen tegen en dit maakt dat de vertolking van de Schrift ook zo verrassend nieuw overkomt. Om het hart en de aandacht van de hoorders te trekken hebben ze niet hun toevlucht gezocht in nieuwe vormen van gemeente - zijn of hebben zij geprobeerd heel populair te preken. Het was bij hen het oude Bijbelwoord gericht op de harten van de mensen. Pastoraal als ze waren wisten ze op die wijze de harten van de mensen te bereiken, omdat ze door de pastorale omgang met de gemeente de noden en de vragen van de mensen verstonden én persoonlijk ook wisten wat voor hen de enige troost was in leven en in sterven. De Schriften werden uitgelegd zonder vrees of compromis, maar met een hart dat verlangde naar de redding van de mensen.

Methodisch hebben ze veel weg van Luther. Deze verfrissende, krachtige profetisch-missionaire manier van preken greep velen aan. Het blijkt dat niet alleen in het Wuppertal maar dat ook in de Finse opwekkingsbeweging van de negentiende eeuw, waar de predikers ook stonden in de traditie van de Reformatie deze wijze van preken gehanteerd werd (Krug, 1957:100 e.v.). Terwijl nu in onze tijd veel predikers uit de negentiende eeuw vergeten zijn en hun preken alleen nog door enkele onderzoekers bestudeerd worden, worden de preken van Krummacher en vooral die van Kohlbrügge door zeer velen in Nederland gelezen en in deze eenentwintigste eeuw nog steeds herdrukt. Wat was het geheim van hun preken en waarom werden zoveel mensen erdoor tot nieuw leven gewekt? 


\section{Karakteristiek van hun prediking}

Wat gebeurt er bij een opwekking? Opwekking is dáár, waar de schat in de akker gevonden wordt; daar waar de kostbare parel je eigendom wordt en de bezitter "met blijdschap heengaat" (Matth. 13:44). Opwekking is dáár waar de Here Jezus Christus verheerlijkt wordt en Hij weer in het centrum van het leven van de kerk geplaatst wordt (Lloyd-Jones, 1992:54). Van deze drie predikers is nauwelijks één preek aan te wijzen waarin zij verzuimd hebben verkondigend op Christus te wijzen. Zij wisten dat ze niet geroepen waren een magneet te zijn die anderen aantrekt en aan hun persoon bindt, maar zij waren wegwijzers naar Jezus Christus. Preken was voor hen niet een neutrale uiteenzetting van wat er in de Bijbel staat, maar voor hen betekende het dat ze zelf waren geraakt door het spreken van God, die in Christus tot hen kwam. Geyser heeft gezegd, dat predikers er niet op uit moeten zijn om mooie preken te houden, maar dat ze erop bedacht moeten zijn "Christi Herrlichkeit der Gemeinde kundzutun" (Geyser, 1923:174). Wie daarom het kruis van Christus preekt, die openbaart daarmee het hoogste en diepste. De geestelijke situatie in hun kerk overziende hebben de Wuppertaler opwekkingspredikers niet alleen gezegd: "We zullen met elkaar voor een opwekking gaan bidden". Natuurlijk hebben zij de noodzaak van het gebed nooit ontkend, maar heel goed hebben zij geweten dat God in het leven van mensen handelend ingrijpt en soeverein is in zijn handelen. God laat door zijn Woord de mensen hun zondige bestaan voor Hem zien en doet hen roepen tot Hem om genade. Wanneer ontstaan opwekkingen? Niet wanneer mensen dit willen organiseren. Opwekkingen laten zich namelijk niet door drukdoende mensen oproepen.

Hoe is het gekomen dat in die tijd toen deze predikers als predikant werkzaam waren, er opwekkingen ontstonden? Deze opwekkingspredikers hebben het Licht laten schijnen in de donkere wereld en in de donkere, zondige levens van mensen en hebben geloofd: de Heilige Geest doet het! Deze predikers hebben niet anders gedaan dan het volle Evangelie te verkondigen en hebben geloofd in de kracht van de Heilige Geest. En zij hebben zó gepreekt dat ze verwachtten dat God door middel van de prediking grote dingen zou uitwerken. Gods wet én het evangelie worden als functies van het Woord van God ten gunste van het evangelie gepreekt, hoewel de preken aandringen op boete en bekering. In deze preken worden soms zeer stevige, ernstige woorden gebruikt, waarin de reformatorische rechtvaardigingsleer duidelijk overheerst. 
In deze prediking wordt dat wat tweeduizend jaar geleden gebeurd is voor ons tegenwoordig gesteld. Dat wat God buiten ons in Christus pro nobis gedaan heeft is pro me! Naast de explicatie van het Woord van God kwam het soteriologische applicatieve voor ons/voor mij. Het zal duidelijk zijn dat in deze preken er een sterke concentratie is op het hart. De ontmoeting tussen God en mens wordt op het hart geconcentreerd als het eigenlijke levenscentrum. Het geweldige is dat de gelovige echter niet teruggeworpen wordt op zichzelf, zijn bekering, op zijn wedergeboorte en op zijn geloof, maar zegt Krummacher, wij worden geworpen op het Lam van God, Christus Jezus.

Was können wir Schöneres sehen, als diese Wunden? Indem sie uns an unsere Missethat erinnern - denn um derselben ward er verwundet - erinnern sie uns zugleich an ihre volkommene Bezahlung. [...] Hier ist Heilung genug; sie ist nicht loss erworben, sie wird auch zugeeignet. Wer wollte nicht Muth fassen, weil die Hände sind durchgraben, die für mich bezahlt haben (Krummacher, 1836:356-357).

De opwekkingspredikers wilden hun gemeenten opbouwen en versterken in het geloof. Methodisch gebruikten ze daarvoor de deductieve wijze van preken. Uitgaande van een centrale waarheid is de prediking gericht op de applicatie. Het komt voor dat deze centrale hoofdwaarheid in het thema van de preek wordt weergegeven. Aan de hand van een bijbeltekst komt het thema in de dispositie van de preek telkens naar voren. Het een wordt afgeleid uit het andere. Vandaar de naam deductieve methode (Klippert, 1995:83-85). Homiletisch gesproken is het these stellend, en wordt de preek in onderdelen opgesplitst en vervolgens toegepast op de bijzondere situatie van de hoorders (Jetter, 1964:46).

Wat de Wuppertalers preekten was volgens hen gelijk aan het "alzo spreekt de Heere". In de prediking komen dan kenmerkende uitspraken als: "Wat ik zeg, geldt in de hemel"; "Indien het u van harte te doen is om vrede met God te hebben, dan zeg ik: in de Naam des Heeren: Het heil is voor u"; "Ik breng u de apostolische prediking". Deze uitspraken uit de preken van Kohlbrügge komen geregeld voor bij deze opwekkingspredikers en laten ons zien dat zij zich geheel en al door God geroepen wisten vertolkers te zijn - net als de oudtestamentische profeten - van het Woord van God. Predikers die "mond Gods" zijn geweest.

Over Kohlbrügge is gezegd - maar het geldt evenzo voor de twee anderen: 
'Mund Gottes' ist er gewesen, weiter nichts. Er hat seinen Zeitgenossen nur Gottes Wort gesagt. Dieses 'Nur' mag Vielen als ein 'Zu wenig' erscheinen; in Wahrheit ist es doch das Grösste, was je und dann gesagt werden, was immer nur dann und da vernommen werden kann, aber auch darf, wann und wo der heilige Gott Sein Schweigen bricht und hervortritt aus Seinem Inkognito, um Sich in dem Zeugnis eines Seiner Knechte der Sünde verhafteten, des Todes schuldigen Söhnen und Töchtern Adams in Seiner ungeschuldeten Güte und in Seiner ebenso unwandelbaren wie unnachahmlichen Treue als Heiland ganz gnädig zu offenbaren (Helbig, 1936:410).

Deze preken waren een hoor-gebeuren, geen visueel-gebeuren. De preken hadden een belerende toon en zonder uitgesproken apologetiek legden de predikanten eenvoudig de Bijbelse uitspraken uit. Het ging deze predikers niet om de intellectuele vragen, maar om de religieuze. Ze waren er niet op uit om de laatste resten van het rechte geloof te redden, maar om levendig geloof te voeden.

Heel bewust stonden deze predikers in de gereformeerde traditie. Zowel in de prediking als in de catechese is in die traditie de onderwijzing een heel sterk punt geweest. Dit in navolging van de Joodse traditie waar het doorgeven van de leerstof een grote plaats innam (en nog steeds inneemt!). Ook in de nieuwtestamentische didache is het aspect van leren groot. Het gaat om het weten, het kennen van de dingen met het oog op het kennen van het heil van God, waarin het gaat om het leven met God. De prediking was afgestemd op een aandringen op persoonlijk geloof en het persoonlijk beleven van het geloof. De Bijbel, het Woord van God, was voor hen bron en criterium van al hun theologische uitspraken. De tekst van de Bijbel was hen heilig. Voor hen waren de woorden van de Bijbel woorden van de Heilige Geest. Deze Woordverkondiging in volmacht en onder leiding van de Heilige Geest bewijst zich als zijnde vol van goddelijke kracht. Het gevaar is er dat door de toenemende automatisering en mechanisering in onze tijd ook de predikers zelf mechaniseren. Een prediker die het verlengstuk is geworden van zijn computer produceert aan de lopende band preken, Bijbelstudies, evangelisatiecampagnes, etcetera, maar het ontbreekt dikwijls aan de kracht van de Heilige Geest. Het gebed is dat God in onze tijd predikers stuurt, die stil zijn voor Hem en die door nauwgezette Schriftstudie het Woord van God vertolken.

De wijze van preken en de boodschap van de Wuppertaler opwekkingspredikers kan voor ons aan het begin van de eenen- 
twintigste eeuw wel eens van een verrassende actualiteit blijken te zijn. Waar in onze tijd alle aandacht ligt op de ervaring van de mens en om het evangelie aan te passen aan onze wensen bieden deze preken de hermeneutische methode voor ons om het evangelie te horen en te verstaan. Gemeenten zullen hun gereformeerd-bijbels karakter behouden zo men gehoorzaam aan de Schrift de vertolking voor de mens van vandaag ter hand neemt. Opwekkingsprediking heeft tot doel dat mensen tot levend geloof in Christus komen en uit dat geloof leven tot eer van God. De Wuppertaler opwekkingspredikers hebben om Paulsen (1973:54) te citeren "de koude gedachten weer brandend gemaakt". Wanneer Kohlbrügge op de kansel stond en begon te preken voelden de mensen intuïtief aan: hier gaat wat gebeuren. Er wordt gezegd: "Wo er auftrat, dort brandete es um inn".

De prediking van deze mensen is geen reformatorische monoloog geweest in de negentiende eeuw, maar zich concentrerend op het hart van het evangelie: hebben zij helder en klaar de boodschap van zonde en genade als van God geroepen gezanten op en pastorale manier verkondigd. Zij putten uit de Bron en deelden het Water des Levens royaal uit. Prediking tussen de polen van boete en geloof. De diagnose werd gesteld en het heil verkondigd. De hoorders werden in de schuilhoeken van hun goddeloosheid opgezocht en zo werd voor hen de weg tot de reddende Christus vrijgemaakt. Hier gaat het om de nieuwe existentie, om ons leven en sterven, het gaat om een leven, dat in het gericht van God kan bestaan. De indicatief van het evangelie, het missionaire element van de verkondiging, het opbouwen van de gelovigen en de troost van het evangelie zijn aspecten die overwegen in deze preken. De kracht van deze preken is dat de hoorder midden in het verhaal geplaatst wordt om daar de levende God als de trooster der zielen te ontmoeten. Zo sterk komt de Christus naar voren dat de gelovige in deze prediking "recht in die Gleichzeitigkeit mit Christus" (Metzger, 1964:128) gebracht wordt.

\section{Missionair-zielszorgerlijke prediking}

Mag deze prediking in het homiletisch koor van onze tijd meespreken? Wanneer wij deze preken nu lezen, dan is het duidelijk dat ze gedateerd zijn. Maar het is bij deze preken net als met die van Luther, wat komen die fris over wanneer deze nu bijna vijfhonderd jaar na dato gelezen worden. Ernstig en opwekkend, nodigend om het heil in Christus te zoeken en uit Hem te leven. 
De boodschap van de reddende Christus dwingt ons om dit in onze tijd ernstig ter harte te nemen. Het is heel gemakkelijk een aantal zaken te noemen waarvan nu gezegd wordt dat men wellicht enkele dingen anders zou moeten zeggen of uitwerken. En er zijn best wat vragen te stellen over de sociale implicaties van deze prediking. Maar ook deze predikers waren kinderen van hun tijd en dat heeft hun prediking gekleurd. En toch, door het bevrijdende van het nochtans van het geloof hebben zij velen die ten dode toe wankelden door hun prediking op de ene Rotssteen, Christus Jezus gesteld en geholpen op de weg door het leven van elke dag (De Reuver, 1989:60-61).

Wanneer van de kansel het Woord van God op een missionairzielszorgelijke manier "einfältig und gewaltig" (Spener, 1986:77) gepreekt wordt, dan gaat onder die prediking iets gebeuren en worden mensen wakker geschud! De geschiedenis van de kerk laat zien dat daar waar opwekkingen waren, deze niet zijn georganiseerd door een enthousiaste groep gemeenteleden. Het is steeds begonnen als een boetebeweging, waar enkelingen of in kleine groepjes, God in het gebed hebben aangeroepen. Daar waar zij een diep besef kregen van de heiligheid van God en van de zwaarte van hun zonden. Het gebed is altijd een kenmerk geweest van een opwekking en het is de prediking geweest waardoor de mensen zijn wakker geschud.

Zo hebben bovengenoemde predikers ons geleerd: in het Woord alléén is onze kracht. In de laatste preekt uit de serie over de Handelingen schrijft Kohlbrügge (1874:238):

O meine Theuersten, das ist das Wunder des Brünnlein Gottes: wo man davon getrunken hat, da schmeckt es Einem so gut, dass man immer wieder auf's Neue um einen Trunk bittet.

Deze geloofsprediking behoudt haar actualiteit. Wanneer er verlangd wordt naar een opwekking, dan blijft over het gebed dat God de hemel scheurt en neerkomt (Jes. 64:1) en Hij zijn kerk bezoekt met zijn heil. En dat zal gebeuren in onze dagen, nu, nu "het Woord des Heren schaars is" (1 Sam. 3:1). In geestelijk donkere tijden, wanneer de mensen moe en moedeloos zijn, gordt God zijn dienstknechten aan, net als Samuël, om klaar en helder te zeggen: "Zo spreekt de Heere". Zulke predikers zijn nodig die gelovig, vol overtuiging het eeuwig blijvende Woord van God uitleggen. Een uitspraak van Robert Sample uit 1897 laat precies zien waar het hier om gaat: 
The great want of today is a holier ministry. We do not need more stalwart polemics, more mighty apologists, or preachers who compass a wider range of natural knowledge, important as these are; but men of God who bring the atmosphere of heaven with them into the pulpit and speak from the borders of another world (Murray, 1998:189).

Zo'n doorvoelde communicatie van doorleefde waarheid, in de kracht en de zalving van de Heilige Geest laat de hoorders niet onberoerd.

Wij leven nu ruim honderd vijftig jaar nadat deze preken in druk zijn verschenen; de letters zijn vergeeld, de taal is hier en daar hoogdravend en doet wat ouderwets aan en tóch deze preken zijn in staat een hart in vlam te zetten. Als ondertitel staat hierboven geschreven: Tussen oprecht verlangen en grote verlegenheid. God kent het intens gebed van zijn kerk om de Heilige Geest en Hij weet van onze grote verlegenheid in deze. Hij weet hoe de Heilige Geest wordt bedroefd en hoe gespot wordt met zijn werk. God mag een ogenblik zijn aangezicht verhullen en zijn hand inhouden, totdat Hij zich opnieuw krachtig openbaart. Zijn wij niet gekomen in diezelfde situatie van Ezechiël waar wij bij deze profeet lezen: "Ik (= God) zocht nu een man uit hen, die de muur mocht toemuren, en voor Mijn aangezicht in de bres staan voor het land, [...]" (Ezech. 22:30). God zoekt een man, een getuige, vertolkers van het Evangelie, mensen die voor zijn aangezicht staan en die zoals Krummacher, Kohlbrügge en Geyser dat in hun tijd hebben gedaan, nu in onze tijd profetisch, krachtig de bazuin aan de mond zetten en het doen horen: "Zo spreekt de Heere!"

Ter afronding een getuigenis van Wilhelm Busch. In de jaren dertig en veertig van de twintigste eeuw was Wilhelm Busch jeugdpredikant te Essen (Duitsland). Toen de geallieerden de stad Essen in de Tweede Wereldoorlog bombardeerden, zat Wilhelm Busch met zijn Bijbel en met een prekenbundel van Krummacher in de schuilkelder. "In all den Stunden, die man im Bunker verbrachte, las ich im 'Krummacher'. Und während draussen die Bomben die Stadt in eine Wüste verwandelten, lies ich mir von inm zeigen, wie Gottes Volk durch die Wüste dieser Welt hindurchgeführt wird." Busch doelt hier op de prekenbundel van Krummacher met 91 preken over de woestijnreis van het volk van Israël uit Egypte naar Kanaän.

De titel van deze bundel is: Die Wanderungen Israels durch die Wüste nach Kanaan. Busch heeft zich steeds afgevraagd: "Hoe komt het dat deze prediking van Krummacher zoveel beweging in de 
gemeente losmaakt?" Hij zegt dan: omdat in deze prediking over de rechtvaardiging erwecklich gepreekt wordt. Als jeugdpredikant wist hij wat voor een impact deze boodschap op de jongeren had. Van deze prediking schrijft hij: "zelfs het jonge volk hoort hiervan op". Hier gebeurt het omgekeerde van wat in deze tijd met het blote oog om ons heen te zien is. Hier zien wij geen stervende, maar een wervende gemeente. Busch $(1965: 109,110,112)$ komt tot de conclusie:

Dann stellt es sich aber heraus, dass Gott sich zu dieser Botschaft bekennt. Und wir dürfen staunend erfahren, dass unter unserer Verkündigung Menschen erweckt werden, Busse tun, unkehren. Und so sah ich Gemeinde entstehen, wirkliche, aktive, lebendige, opferfreudige, missionswillige Gemeinde.

Inderdaad, zo gebeurde het, zo gebeurt het én zo zal het gebeuren a.D. 2007. God, Die de hemel opent en Zijn volk bezoekt!

Opwekking? Wanneer? Het ligt in Gods handen! Bij wat hierboven geschreven staat, is het goed om Handelingen 3:1-26 tot ons door te laten dringen. In dit Bijbelgedeelte is sprake van een genezing van een verlamde man. Deze man springt na zijn genezing als een hert door de tempel, terwijl hij God uitbundig looft en dankt. Petrus wijst vervolgens de aandacht af van deze man en laat de mensen het machtige handelen van God zien. Zijn knecht Jezus - zoals Petrus Hem noemde - werd door God verheerlijkt, maar door mensen overgeleverd en gekruisigd. Wat mensen gedaan hebben is zeer ernstig, "maar (!) God heeft Hem opgewekt uit de doden, waarvan wij getuigen zijn" (v. 15). En dan klinkt het appèl tot de mensen die Petrus hoorden: "Komt dan tot berouw en bekering, opdat uw zonden uitgedelgd worden, opdat er tijden van verademing mogen komen van het aangezicht des Heren." Zó zal het komen. Wanneer mensen de weg gaan van oprecht berouw en bekering, zal God in onze tijd tijden van geestelijk opleven en ontwaken, tijden van verademing geven! Door oprecht berouw en bekering is vergeving en verzoening mogelijk: verzoening met God, maar ook met broeders en zusters onderling. Op deze manier komt er een einde aan het verhinderen van de Heilige Geest om in en door ons te werken.

Laten wij, niet opdringerig, maar indringend bidden: Kom, (Her) Schepper, Heilige Geest, kom verlevendig ons! Laat de tijd van verademing komen.

Met de kerk van alle tijden en plaatsen zeggen wij: 
God of Eternity, Lord of the Ages,

Father and Spirit and Saviour of men!

Thine is the glory of time's numbered pages;

Thine is the power to revive us again.

(Merrington, 1998 [1927]:193).

\section{Geraadpleegde bronnen}

BARRS, J. \& PACKER, J. 1998. Hart's tocht naar God! Over het werk van de Heilige Geest in het leven van de gelovige. Hazerswoude: Grace Invest.

BAVINCK, J.H. z.j. Ik geloof in de Heilige Geest. Den Haag: Voorhoeve.

BENRATH, G.A. 2000. Die Erweckung innerhalb der deutschen Landeskirchen 1815-1888. (In Gäbler, U. Geschichte des Pietismus. Band 3. Göttingen: Vandenhoeck \& Ruprecht. S. 150-271.)

BEYREUTHER, E. 1978. Geschichte des Pietismus. Stuttgart: Steinkopf.

BOHREN, R. 1975. Dass Gott schön werde: praktische Theologie als theologische Ästhetik. München: Kaiser.

BUSCH, W. 1965. Plaudereien in meinem Studierzimmer. 2. Aufl. Gladbeck: Schriftenmissions Verlag.

CHRISTLIEB, Th. 1893. Homiletik. Basel: Jaeger \& Kober.

EDWARDS, J. 1999. Jonathan Edwards on revival. (In Edwards, J. Jonathan Edwards' selected words. 6th reprint. Edingburgh: The Banner of Truth Trust. p. 75-147.)

ESCHBACH, H. Olie op het vuur: een boekje over de evangelische beweging binnen de traditionele kerken. 4e. dr. Apeldoorn: Novapres.

GÄBLER, U. 1991. Auferstehungszeit: Erweckungsprediger des 19. Jahrhunderts. München: Beck.

GEYSER, P. 1923. Gesammelte Schriften. Bd. VI. Elberfeld: Friderichs.

HELBIG, G. 1936. H.F. Kohlbrügge, ein Lehrer unserer Tage. Junge Kirche, IV.

HERZOG, R. s.a. Die Wiskottens. 101-110 Aufl. Die Wiskottens.

HUGHES, S. 1990. Revival: times of refreshing, Eastbourne: Kingsway Publications.

JETTER, W. 1964. Wem predigen wir. Stuttgart: Calwer.

KLIPPERT, W. 1995. Vom Text zur Predigt: Grundlagen und Praxis biblischer Verkündigung. Wuppertal: Brockhaus.

KOHLBRÜGGE, H.F. 1874. Apostelgeschichte: Cap. 2-10, in fünfundzwanzig Predigten im Jahre 1873 gehalten. Elberfeld: Niederländisch-reformirten Gemeine.

KOMMERS, J. 2005. "Ontwaakt, gij die slaapt!" Het reformatorisch getuigenis van Gottfried Daniel Krummacher, Hermann Friedrich Kohlbrügge en Paul Geyser tijdens de Erweckung in het Wuppertal van de negentiende eeuw. een bijdrage tot de preek en vroomheidsgeschiedenis van de negentiende eeuw. Heerenveen: Groen/Jongbloed. (Ph.D.-proefschrift.)

KRUG, B. 1957. Die Rechtfertigungslehre in der finnischen Erweckungsbewegung im 19. Jahrhundert und ihre Bedeutung für Seelsorge und Verkündigung. Düsseldorf: Triltsch.

KRUMMACHER, Fr. W. 1935. Gottfried Daniel Krummacher und die niederrheinische Erweckungs-bewegung zu Anfang des 19. Jahrhunderts. Berlijn: Gruyter. 
KRUMMACHER, G.D. 1836. Wahrheit zur Gottseligkeit (Hauspostille). Meurs: Rheinischen Schulbuchhandlung.

LEHMANN, H. 2000. Die neue Lage. (In Gäbler, U., Hsg. Der Pietismus im neunzehnten und zwanzigsten Jahrhundert: Geschichte des Pietismus. Band 3. Göttingen: Vandenhoeck \& Ruprecht. S. 1-26.)

LLOYD-JONES, D.M. 1992. Toon mij nu Uw heerlijkheid! Over de noodzaak van opwekking. Leiden: Groen.

LLOYD-JONES, D.M. 2002. Howell Harris and Revival, (In Lloyd-Jones, D.M. The Puritans: their origins and successors. 5th repr. Edingburgh: The Banner of Truth Trust. p. 282-302.)

MACFARLAN, D. 1988. The revivals of the eighteenth centuary, particulary at Cambuslang with three sermons by the Rev. George Whitefield. Glasgow: Free Presbyterian Publication.

MERRINGTON, Ernest N. 1998 [1927]. The church Hymnary, no. 642. (In Murray, I.H. Pentecost-today. Edinburgh: The Banner of Truth Trust. p. 193.)

METZGER, H. 1964. Kriterien christlicher Predigt nach Sören Kierkegaard. Göttingen: Vandenhoeck \& Ruprecht.

MURRAY, I.H. 1998. Pentecost - today? The Biblical basis for understanding revival. Edinburgh: The Banner of Truth Trust.

NEUSER, W.H. 1977. Pietismus und Erweckungsbewegung - der bayrische Erweckungstheologie Christian Krafft (1784-1845). (In Lindt, A. \& Deppermann, K. Pietismus und Neuzeit. Bielefeld: Luther Verlag. S. 126210.)

ORR, J.E. 1975. The eager feet: evangelical awakenings, 1790-1830. Chicago: Moody Press.

PAULSEN, A. 1973. Menschsein heute: Analysen aus Reden Sören Kierkegaards. Hamburg: Wittig.

REUVER, A. DE. 1989. Kohlbrugge: prediking van hart tot hart. (In Knevel, A.G., red. Bevindelijke prediking. Kampen: Kok. p. 55-62.) (Theologische Verkenningen, 6.)

SMITZ, O. 1956. Pietismus und Theologie. Neukirchen: Buchhandlung des Erziehungsvereins.

SPENER, P.J. 1986. Pia Desideria. Opnieuw bearbeid door E. Beyreuther onder de titel: "Umkehr in die Zukunft, Reformprogramm des Pietismus Pia Desideria." 4. Aufl. Giessen: Brunnen Verlag.

STRAUSS, G.F.A. 1868. Abend - Glocken - Töne: erinnerungen eines alten Geistlichen aus seinem Leben. Berlin: Wiegand \& Grieben.

THOLUCK, F.A.G. 1823. Die Lehre von der Sünde und vom Versöhner. Hamburg: s.n.

THOMAS, I.D.E. 1997. God's harvest: the nature of true revival. Revised edition. Bryntirion: Gwasg Bryntirion Press.

WALLIS, A. 1956. In the day of Thy power. Eastbourne: Kingsway Publications. ZAHN, A. 1881. Der Grossvater: ein Lebensbild. Stuttgart: Greiner \& Pfeiffer. 


\section{Kernbegrippen:}

deductieve preekopvatting

Elberfeld, Wuppertal

Geyser, P.

Kohlbrügge, H.F.

Krummacher, G.D.

opwekking

opwekkingsprediking

reformatorische traditie

\section{Key concepts:}

deductive preaching method

Elberfeld, Wuppertal

Geyser, P.

Kohlbrügge, H.F.

Krummacher, G.D.

reformed tradition

revival

revival sermons 